\title{
OTHER COILING CHANGES IN GLOBOROTALIA ACOSTAENSIS UNKNOWN TILL NOW IN MEDITERRANEAN AREA
}

\author{
S. PRILLO ${ }^{1}$, J. MEHAJ ${ }^{1}$ AND J. PRILLO ${ }^{1}$
}

\begin{abstract}
In this study, all samples from Tortonian to Early Pliocene sediments of Zvernec-Vlora and Kavaja-Durres regions within Peri-Adriatic Foredeep (PAF) of Albania containing Globorotalia acostaensis were studied qualitatively and quantitatively. Baseci on these analyses resulted that G. acostaensis have changed coiling ratio direction during $G$. acostaensis and G. obliquus extremus Zone of Tortonian, differently from that known in Mediterranean area up to now. This is not a short time interval, which more exactly is from the first appearance of $G$. acostaensis to first appearance of $G$. suterae, at the upper part of G. extremus Zone. Another documented and explaining unconformity here is related with beginning of Pliocene sediments. There are at least four altenating sinistral and dextral coiling changes in G.acostaensis populations. Also in this work is given the history of the study of $G$. acostaensis and which maybe causes that this species in Mediterranean province and especially in our country is used relatively late as zonal marker species.

The main object of stratigraphers and paleontologists has been finding a successive section, with uninterrupted sedimentation, possibly for the longest geological time. Regarding to this phenomenon could be explained resulting unconformity between coiling ratio changes in Globorotalia acostaensis of the present study and other studies carried out in Mediterranean area on this occasion up to now. It is difficult to understand here the resulting unconformity during the main part of Tortonian age, which prolonged more than 2 m.y. Another resulting unconformity discovered at the Miocene/Pliocene boundary of the Kavaja-Durres regions is very significant. In these regions was discovered an earlier Pliocene sedimentation than known up to now according to resulting alternations of coiling direction of Globorotalia acostaensis prior to Pliocene Sphaeroidinellopsis Acme zone. These data are in favour of those based on the isotopic stratigraphy, which give a new definition at 5.32 M.Y. Miocene/Pliocene boundary instead of 5.1 or $5.2 \mathrm{M}$.Y. given previously based on absolute age. Coiling changes, in our case that of $G$. acostaensis are in response to changing climates or alternation of different cold and warm water populations resulting from changes in the boundaries between water masses as at the beginning of the Pliocene when the water masses of the Atlantic Ocean overflowed the Mediterranean area. Here is also proposed to correct the Neogene paleoclimatic curve referring, for the interval of G. acostaensis range distribution.
\end{abstract}

KEY WORDS: Planctonic foraminifera, Globorotalia acostaensis, Zonal marker, Paleoclimate, Ionian Zone

\section{INTRODUCION}

The present study is focused in two regions (Fig. 1). Thus Zvernec section in the south (Vlora region) and Kavaja section (Kavaja-Durres region) in the northern part of PAF, represent two main sections on which it is based. The both regions where previously surveyed and sampled by our geological service but taken samples for microfauna have never resulted so rich in planktonic foraminifera as these taken last time by Kumati et al. (1999). Here it is necessary to remark that only main part of Tortonian of the both sections is useful for planktonic foraminiferal study. The rest part of the Zvernec section is not exposed, therefore instead of it, here are used some cores of Narta-2, Vlora-12, Orikum-1, boreholes (Fig.1,2). Also in Kavaja the other part of section from uppermost part of Tortonian up to the base of Pliocene is very well exposed but shallow sediments of this part also are not available for the evolutionary study of Globorotalia acostaensis. For that here also are used core samples from Durres-7 borehole and some outcrops all around Kavaja section, which represent the only exposures of Messinian deep-sea sediments in Albania 


\section{PREVIOUS WORK}

Globorotalia acostaensis was originally described by Blow W. H (1959) from late Miocene of Venezuela, Caribbean area (Blow, 1959). This species was used by Bolli \& Bermudez and Bolli, 1966 (referring Bolli, 1966) as zonal marker of their $G$. acostaensis Zone.

Later on G. acostaensis was used as zonal marker in Mediterranean area (Bizon \& Bizon, 1972), where the upper boundary of their zone defined by first occurrence of two zonal markers Globorotalia dutertrei (d'Orbigny) and G. humerosa Takayanaki \& Saito.

In 1982 and 1985 G.acostaensis was also used as zonal marker in Italy (Iaccarino, 1985). The upper boundary of their zone in the both cases marked by first occurrence of Globigerinoides obliquus extremus Bolli \& Bermudez. Such an interval with G. acostaensis zonal marker was also established by Prillo \& Hasanaj 1994 in Albania

The above-mentioned data show for a delay in use of G. acostaensis as zonal marker in Mediterranean area and in our country. It is probably related with its rare occurrence and with difficulties in its determination.

\section{COILING RATIO CHANGES IN G. ACOSTAENSIS}

In the both regions studied has a complete conformity in coiling ratio changes during entire its stratigafic range. In contrast a great unconformity in coiling changes of $G$. acostaensis especially during Tortonian between our data and them recorded in Mediterranean area (Bolli \& Saunders, 1985). Thus, from first appearance of $G$. acostaensis, close to early part of Tortonian and during the lower part of G. acostaensis Zone over $80 \%$ specimens of Kavaja section prefer sinistral coiling, while in Zvernec section these are over 90\% (Fig. 2,3). Onward, almost in the middle of $G$. acostaensis Zone a sudden change from sinistral to dextral occurs in the both sections.

In Zvernec this preference for dextral coiling coincides with sample nr.16 while in Kavaja coincides with sample 280 where such a preference develops also Globorotalia continuosa Blow. In Zvernec its very sporadically occurrence does not allow us to say which coiling does it prefer in this section. Dextral coiling remains such a coiling during upper part of $G$. acostaensis Zone and the lower part of the successive $G$. extremus Zone up to the first occurrence of Globorotalia suterae.

In the Mediterranean area (Bolli \& Saunders, 1985) instead of dextral coiling reported only the sinistral coiling remaining such not only for the interval above-mentioned but still higher up to the first occurrence of Globigerina multiloba Romeo (Fig. 4).

In consequence, resulting differences in coiling preferences occur within the Mediterranean area. According to Jenkins (1967) and Bolli (1971) such local differences in coiling preferences with one species are dependent on the temperature of the water. These sayings are valuable for Miocene to Recent species. If we are agreeing with them we must admit within Mediterranean area during the most part of Tortonian two different climate regions at the same time. In the interval from first occurrence of $G$. suterae to first occurrence of $G$. multiloba demonstrated an opposite coiling within the previous one of this study and again specimens of G. acostaensis prefer dextral coiling which is in conformity with the Mediterranean area. The Kavaja section and Guri i Bardh exposure (Fig. 1,3) apparently represent an earlier Pliocene section in Mediterranean area. Here for the first time are found deep-sea sediments prior to Pliocene Sphaeroidinellopsis Acme zone (Fig. 4).

\section{STRATIGRAPHIC AND PALEOCLIMATIC IMPLICATION OF COILING CHANGES IN GLOBOROTALIA}

Fig. 5 gives the preferable coiling changes of several Globorotalia species studied in Ionian Zone of Albania, from middle Miocene to early Pliocene. Most species demonstrated here belong to genus Globorotalia s.l. and are its integrated species like G. mayeri, G. continuosa, G. acostaensis and G. pachyderma, which is not occurred in our samples. Globorotalia menardii make an exception in our case, perhaps because it belongs to Globorotalia s.s. According to Bolli (1971) this species demonstrated the local differences in coiling preferences between tropical Caribbean area and tropical Pacific area. Within Mediterranean this species has not any differences in coiling preferences from each to other regions. It is rather a cold-water species. Its coiling change from sinistral to dextral at the top of Tortonian seems to be in unconformity with sinistral coiling of G.acostaensis, however we do not say that $G$. menardii, its dextral coiling do not reflect any climatic change because it dependent on individual species. Thus, in G. menardii after coiling change suddenly occurs also its disappearance giving in this way a marked stratigraphic level. Other aspect should be the interval with dextral coiling in G. acostaensis during most part of Tortonian. In sampled interval of the both sections no one specimens of G. menardii occur. Believing that coiling changes in $G$. acostaensis coincide with climate changes, we corrected the paleoclimatic curve given by Bizon \&Muller (1977) (Fig. 5). 

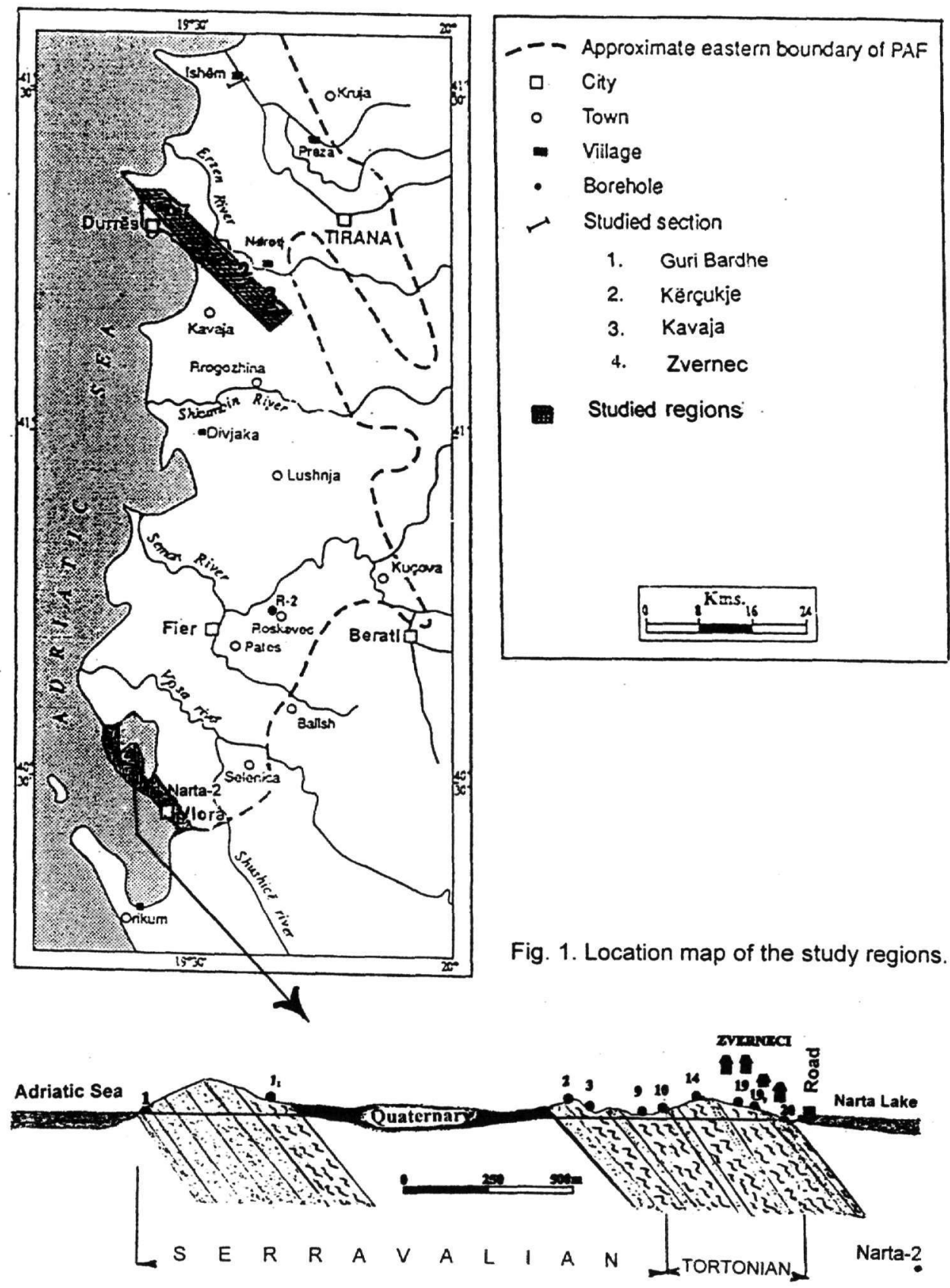

In Kavaja-Durres region at the base of its Pliocene sediments was found an interval represented by 4 alternative coiling directions, which give confirmation on our knowledge for Miocene-Pliocene sediments of our region. These alternations of different cold and warm water masses entered into Mediterranean from Atlantic Ocean. By the end of this interval, within Sph. A. zone, prior to the first occurrence of G. margaritae Bolli \& Bermudez was established a stability of water temperature between Atlantic and Mediterranean Sea, towards a warm climate. Remaining dextral coiling during the rest part of early Pliocene was also in response of warm water early Pliocene populations. These data are also in favor of them based on the isotopic stratigraphy which give a new definition at 5.32 M. Y. Miocene/Pliocene boundary instead of 5.1 or $5.2 \mathrm{M}$. Y. given previously based on absolute age. 


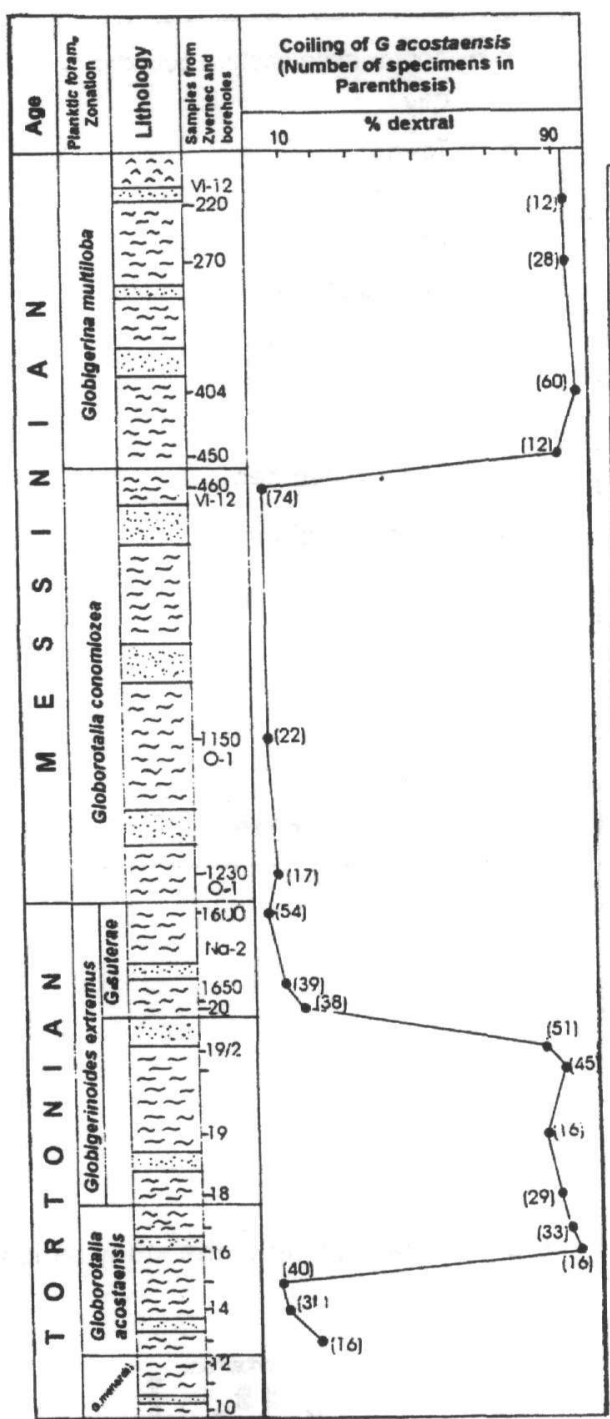

Fig. 2: Coiling changes in $G$ acostaensis, Zvernec section and boreholes all around.

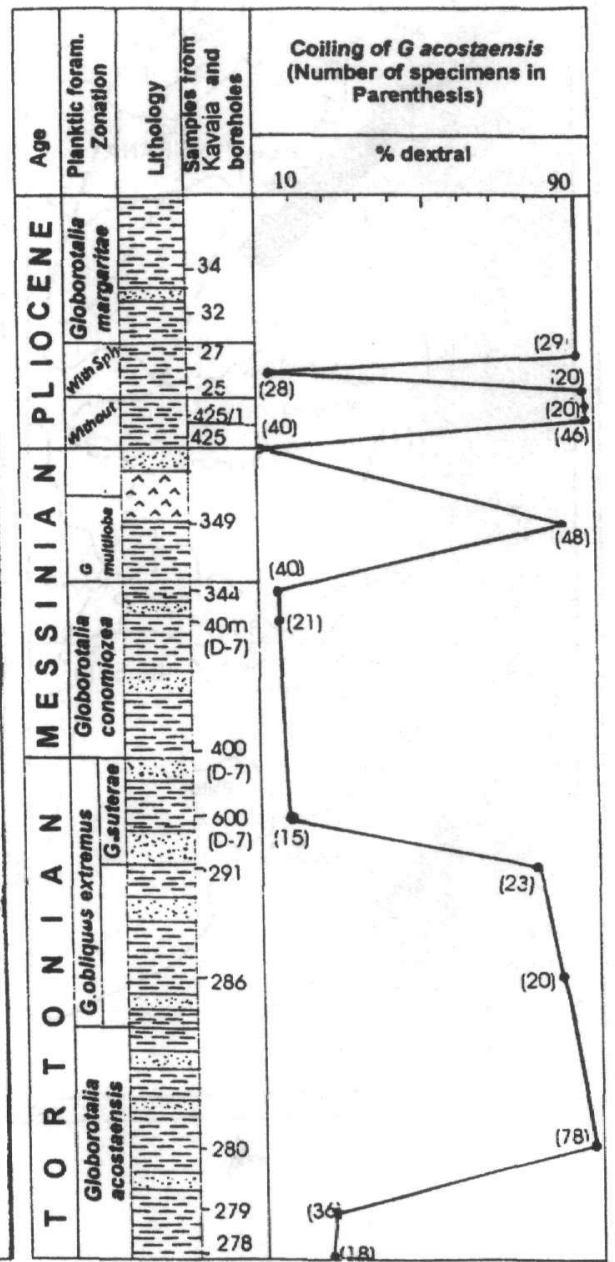

Fig. 3: Coiling changes in $\mathbf{G}$ acostaensis, Kavaja section and boreholes all around. 


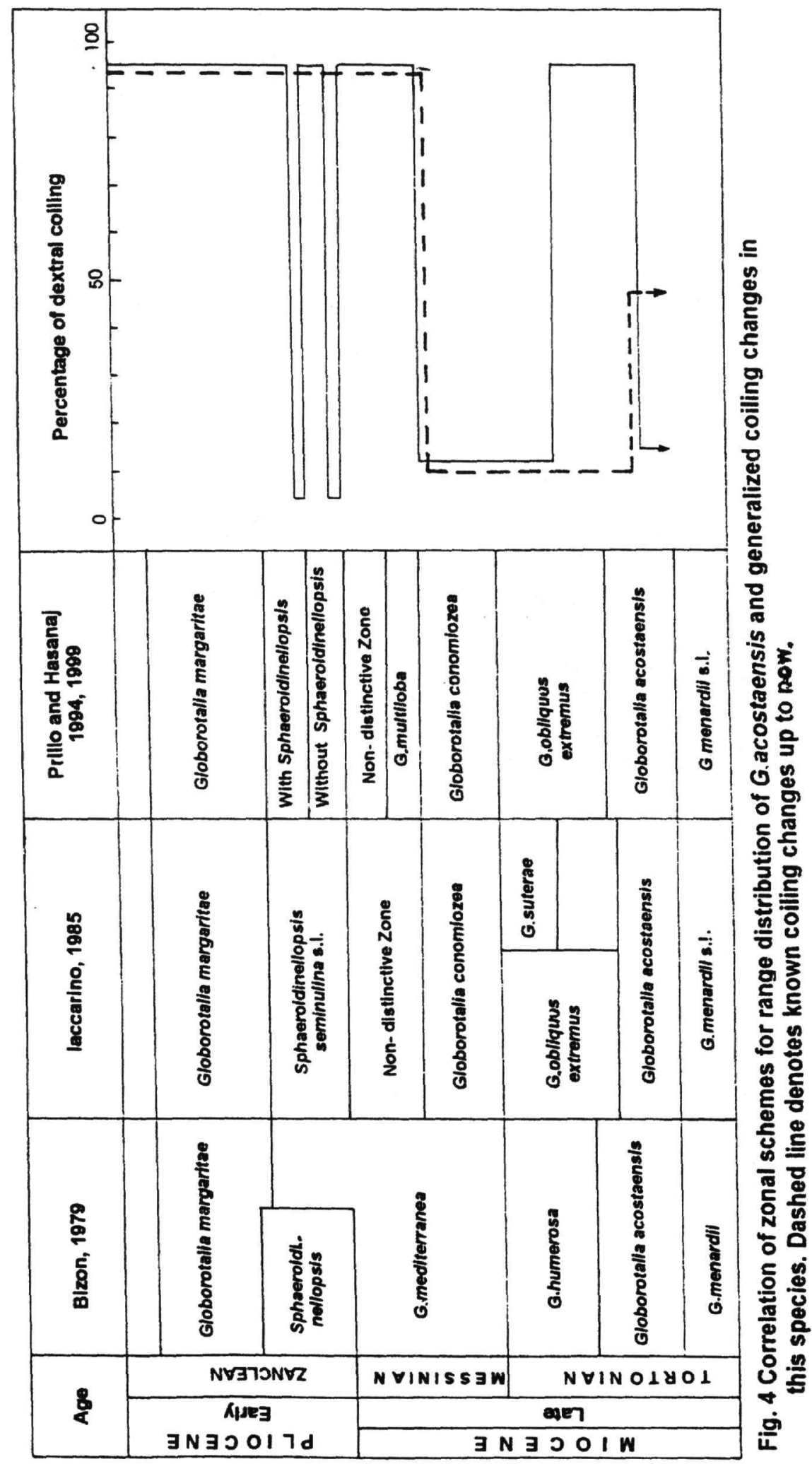

-553 - 


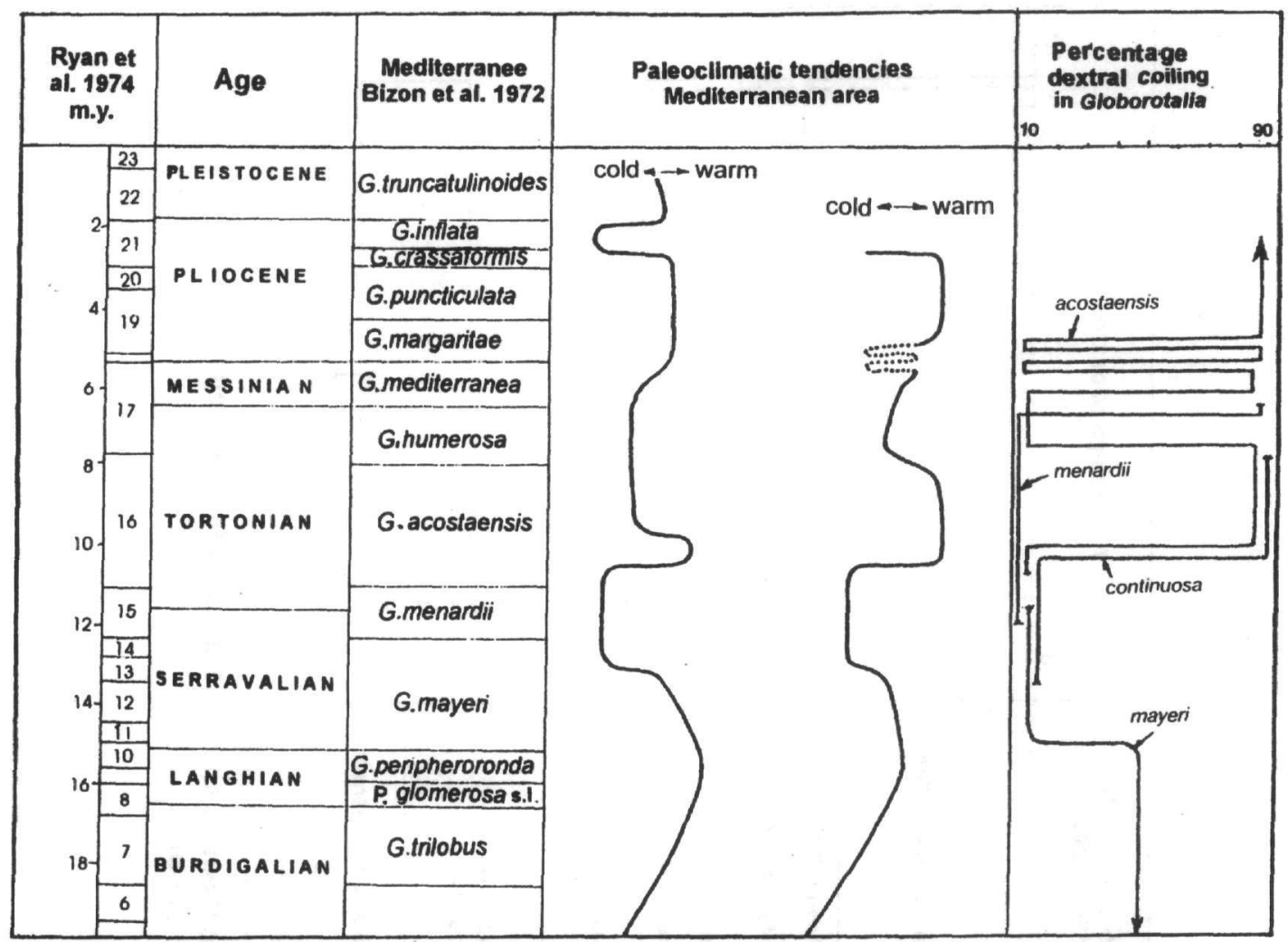

Fig. 5 Correction of Neogene paleoclimatic curve for the interval of $\mathrm{G}$ acostaensis range distribution

\section{REFERENCES}

Bizon G.et Bizon J.J. 1972.- Atlas des principaux foraminifӨres planctoniques du bassin Miditerranten. Oligoc $\theta$ ne vi Quaternaire. Editions Technip, Paris, $316 \mathrm{pp}$.

Bizon G. \& Muller C. 1977. - Remarks on some biostratigraphic problems In the Mediterranean Neogene. In : Intern, Symp. Struct. Hist. Med. Basins Split (Yugoslavia) 1976. Technip pp. 381-390.

Blow W.H. 1959.- Age, correlation, and biostratigraphy of the upper Tocuyo (San Lorenzo) and Pozon formations, Eastern Falcon, Venezuela. Bull. Amer. Paleont., 67, 39-252

Bolli H.M. 1966 a.- Zonation of Cretaceous to Pliocene marine sediments based on planktonic foraminifera. Boletin informativo Asociacion Venezolana de Geologia, Minieria y. Petroleo, 9 (1), 3-32.

Bolli H.M. 1971.- The direction of coiling in planktonic foraminifera. In: The Micropaleontology of Oceans, ed. B.M. Funnell et W.R. Riedel, pp.639-648 Cambridge University Press.

Bolli H.M. \&. Saunders I.B. 1985.- Oligoecene to Holocene low latitude planktic foraminfera. Plankton Stratigraphy. Cambridge University Press.p. 155-262.

Iaccarino S. 1985.- Mediterranean Miocene and Pliocene planktic foraminifera. Plankton Stratigraphy Cambridge University Press. p. 283-314.

Jenkins D.G. 1967. Recent distribution, origin and coiling ratio changes in Globorotalia pachyderma (Ehrenberg). Microp. 13, no 2, p. 195-203.

Kumati L1., Prillo S., Buli K. 1999.- Deshifrimi stratigrafik i depozitimeve detare dhe liqenore te Messinianit ne baze te ostrakodeve ne rajonin Vlore-Durres. Fondi ING. Fier.

Prillo S. et. Hasanaj L. 1994.- Studimi kompleks biostratigrafik i depozitimeve te Miocenit te mesem e te siperm qe perfshijne ndertimin gjeologjik te kateve Langhian, Serravalian, Tortonian e Messinian sipas stratotipeve te Mesdheut, Fondi ING Fier.

Prillo S. et. Hasanaj L. 1999.- Biostratigrafia dhe interpretime Paleoekologjike per depozitimet e Pliocenit ne Shqiperi, Fondi ING Fier, Albania. 